\title{
Use of non-destructive testing for the evaluation of the preservation state of Iquique Clock Tower, Chilean Historic Monument
}

\section{Utilización de técnicas no destructivas en la evaluación del estado de conservación de la Torre del Reloj de Iquique. Monumento Histórico Nacional de Chile}

Rodrigo Osvaldo Ortiz Mansilla (Main Author - Corresponding Author)

Escuela de Construcción Civil, Facultad de Ingeniería, Universidad de Valparaíso, Valparaíso (Chile) General Cruz 222, Valparaíso rodrigo.ortiz@uv.cl

\section{Nicol Alejandra Fuentes Sazo}

Escuela de Construcción Civil, Facultad de Ingeniería, Universidad de Valparaíso, Valparaíso (Chile) General Cruz 222, Valparaíso

nicol.fuentess@alumnos.uv.cl

Andrés Eduardo Jamet Aguilar

Escuela de Construcción Civil, Facultad de Ingeniería, Universidad de Valparaíso, Valparaíso (Chile) General Cruz 222, Valparaíso

andres.jamet@uv.cl

\section{Alberto Aníbal Moya Arredondo}

Escuela de Construcción Civil, Facultad de Ingeniería, Universidad de Valparaíso, Valparaíso (Chile) General Cruz 222, Valparaíso

alberto.moya@uv.cl

\section{Mauricio Andrés González Moya}

Escuela de Construcción Civil, Facultad de Ingeniería, Universidad de Valparaíso, Valparaíso (Chile) General Cruz 222, Valparaíso

mauricio.gonzalez@uv.cl

\section{María Paz Varela Díaz}

Escuela de Construcción Civil, Facultad de Ingeniería, Universidad de Valparaíso, Valparaíso (Chile) General Cruz 222, Valparaíso mariapaz.varela@uv.cl

\section{Aldo Augusto Ramírez Guerra}

Escuela de Construcción Civil, Facultad de Ingeniería, Universidad de Valparaíso, Valparaíso (Chile) General Cruz 222, Valparaíso

aldo.ramirez@uv.cl

\section{Erik Baradit Allendes}

Departamento de Física, Facultad de Ciencias, Universidad del Bío Bío, Concepción (Chile) Avenida Collao 1202, Casilla 5-C, 4051381 Concepción, Chile aldo.ramirez@uv.cl

\section{Patricia Haydée Martínez Ramírez}

Escuela de Construcción Civil, Facultad de Ingeniería, Universidad de Valparaíso, Valparaíso (Chile) General Cruz 222, Valparaíso patricia.martinez@uv.cl

Manuscript Code: 1160

Date of Acceptance/Reception: 25.07.2019/16.08.2018

DOI: 10.7764/RDLC.18.2.238 


\section{Abstract}

The Clock Tower, a typical expression of the saltpeter period, is located in Arturo Prat Square in Iquique, Chile. The building, completely made of wood, has endured the passing of time without major modifications. There is concern about its conservation state. However, there are no records of in-depth evaluations that determine its conservation state. The present study, carried out through the use of non-destructive testing (NDT), is an evaluation of its current state. Basic inspection and structural analysis were also included. The results indicate that the wood of the building corresponds to the species Pseudotsuga menziesii (Oregon Pine). The basic inspection does not reveal any significant damage. However, there is evidence of attacks by insects in the larval stage, social insects and brown rot fungi. Abiotic deterioration by defibering is also observed. NDT studies-ultrasound, resistography and xylo hygrometry-allowed the estimation of density and static modulus of elasticity (MOE) in bending. The low density of wood is shown in a static MOE value of only 4.4 GPa. According to Chilean regulations, wood elements were classified as structural class F3. However, the structural analysis determined that the working stresses did not exceed the admissible stresses. At the foundations level, it is necessary to perform intervention actions.

Keywords: clock tower, evaluation, wood, NDT, MOE.

Resumen

La Torre del Reloj, una expresión representativa del período salitrero, se encuentra ubicada en la plaza Arturo Prat de Iquique - Chile. El edificio, construido íntegramente en madera, ha sobrellevado el paso del tiempo sin grandes modificaciones. Existe preocupación respecto a su estado de conservación. Sin embargo, no hay registros de evaluaciones profundas que determinen su actual condición. El presente estudio, realizado mediante la utilización de técnicas no destructivas (NDT), es una evaluación de su actual estado. Se consideró, además, inspección básica y análisis estructural. Los resultados indican que la madera del edificio corresponde a la especie Pseudotsuga menziesii (Pino Oregón). La inspección básica no da cuenta de daños significativos. No obstante, se evidencia el ataque de insectos de ciclo larvario, insectos sociales y hongos de pudrición café. Deterioro abiótico por desfibrado también es observado. Los estudios realizados mediante NDT- ultrasonido, resistografía y xilohigrometríapermitieron la estimación de la densidad y del módulo de elasticidad (MOE) estático en flexión. La baja densidad de la madera se manifiesta en un valor de MOE estático de solo 4,4 GPa. De acuerdo a la normativa chilena los elementos de madera fueron asimilados a la clase estructural F3. No obstante lo anterior, el análisis estructural determinó que las tensiones de trabajo no superan las tensiones admisibles. A nivel de fundación es necesario realizar acciones de intervención.

\section{Introduction and description of the problem}

Wood is the material that has accompanied the human being uninterruptedly from the most remote ancient times to the present day (Rodríguez, 1998). This material is deteriorated by a wide variety of biotic and abiotic mechanisms.

The process of evaluating wooden buildings involves a series of simultaneous studies (Coscollano, 2003). In many cases, their condition and characteristic prevent the collection of large samples for analysis, so the use of NDT is required to complement the studies (Rodríguez, 1998). NDT is used to evaluate different physical and/or mechanical properties. It is also used to detect and evaluate defects in a part or structure without altering its capabilities (Tanasoiu et al., 2002). In the case of wood, these techniques can be used to assess the damage caused by biodeterioration agents (Ross and Pellerin, 1994), or to detect defects and characterize the mechanical properties of wood and composite materials (Emerson et al., 1998). The application of NDT, for the evaluation of historic wooden buildings, has been extensively developed (Basterra et al., 2017; Ortiz et al., 2017; Basterra et al., 2009; Basterra et al., 2008).

The clock tower (Figure 1)-built under the Peruvian Regime-is located in Arturo Prat Square in Iquique, Chile (Fox, 2012). Its construction was performed as a replacement for the clock of the main tower of the Main Church that was destroyed in a big fire in June 1873 (Donoso, 2003).

The design of this building is attributed to the engineer Manuel Lapeyrouse (Mineduc, 1987). The construction was located in the middle of the square, facing the axis of the current Luis Uribe Street (Advis, 2009). Its inauguration was held at the beginning of 1879, a few months before the start of the War of the Pacific (Donoso, 2003; Advis, 2009). Together with the clock tower, there are other buildings that constitute urban expressions that are typical of the saltpeter period of the city, such as the municipal theater, the society for the protection of the theater of Tarapacá, the Spanish social club and the Croatian club (Fox, 2012).

The 24.58-meter-high clock tower was built of wood based on three square section stepped bodies. However, it is possible to distinguish five levels before reaching the ceiling structure. In their three bodies, there are pointed, scalloped and trefoil arches interpreting a Mudejar style. The building was declared a National Historic Monument in 1987 (Mineduc, 1987).

There is concern about its conservation state. However, there are no records of in-depth evaluations that determine its current condition. The development of intervention actions in the building for its maintenance and preservation 
will require the evaluation of construction elements and its structural condition. The present study aimed at the diagnosis of the preservation state of Iquique clock tower through the use of NDT.

\section{Materials and methods}

\section{Place of study and location}

The place of study corresponds to Iquique clock tower located in the Tarapacá Region, Iquique Province, Chile. Latitude and longitude coordinates are: $20^{\circ} 12^{\prime} 51^{\prime \prime} \mathrm{S}, 70^{\circ} 9^{\prime} 9^{\prime \prime} \mathrm{W}$.

\section{Evaluation methodology}

The proposal by Basterra et al. (2009) was taken into account. This methodology states a study whose results are derived from a basic inspection, an instrumental inspection and a structural analysis.

\section{Basic and instrumental inspections}

The basic inspection was carried out in accordance with the statements of Ortiz et al. (2015). The instrumental inspection considered the following NDT: wood hygrometry, ultrasonic wave propagation speed, sensors of temperature/relative humidity and resistography. In addition, planimetry, altimetry and optical microscopy tasks were performed in order to identify wood species and to determine damages within the material.

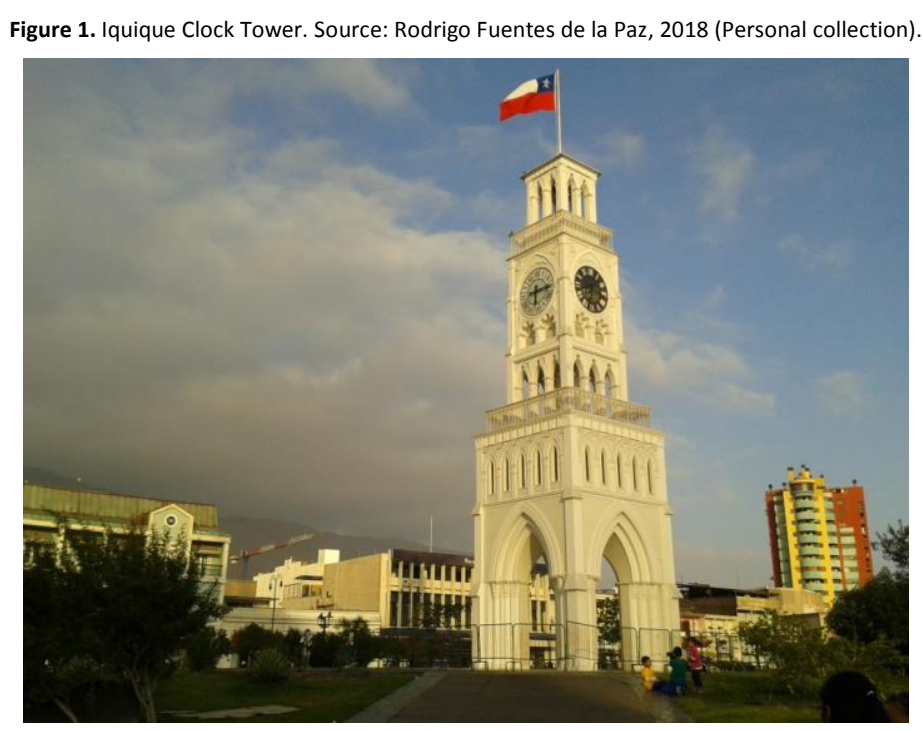

For the analyses through optical microscopy, small wood samples from the clock tower were extracted. For each level three samples were taken at a height of 0.5 . The obtained samples were placed in sterile plastic bags and were sent to the Laboratory of Biodeterioration and Biodegradation of Materials (from the Spanish, Laboratorio de Biodeterioro $y$ Biodegradación de Materiales) of the Civil Construction School of Universidad de Valparaíso, where they were stored at $4^{\circ} \mathrm{C}$. The samples were prepared by using the techniques previously described by Blanchette \& Simpson (1992). The microscopic observation and photographic capture were made through an optical microscope. The microscopic identification was carried out through the use of keys, according to the indications of Díaz Vaz (1979).

The studies of wood hygrometry, ultrasound, altimetry and planimetry were carried out in accordance with the information given by Ortiz et al. (2015). The records of temperature/relative humidity were developed for a fifteenday-period through Escort RH llog instruments. Moisture content measurements were made through a xylo hygrometer MWD-14A Minipa. In the determination of the ultrasonic speeds a $54 \mathrm{Khz}$ longitudinal polarity V-meter MK IV James Instruments Inc. was used. Resistographic measurements were made through a Resistograph 4453-S Scientific Rinntech.

The evaluation through NDT considered the main resistant elements from the five levels of the building, including the foundations. The construction conditions of the tower impeded the ultrasound measurement in the third, fourth and fifth levels. Temperature and relative humidity measurements for the fourth and fifth levels were not included. 
Wood density was determined from the results obtained through resistography. The dynamic MOE was determined through the relationship between the ultrasonic wave propagation speed and the density of the wood using equation 1. The value obtained was related to the static MOE in flexion as established by Chauhan \& Sethy (2016).

\author{
$\rho=$ density \\ $\mathrm{V}_{\text {us }}=$ ultrasonic wave propagation speed
}

\section{Modeling and structural analysis}

The modeling and structural analysis was developed by taking into account the background information obtained in the basic and instrumental inspections. The modeling also considered the use of NCh 3171 Of. 2010: Structural designGeneral provisions and load combinations (from the Spanish, Diseño estructural - Disposiciones generales y combinaciones de cargas) (INN, 2010) and NCh 433 Of. 1996: Seismic design of buildings (from the Spanish, Diseño sísmico de edificios) (INN, 1996). SAP 2000 v20 software was used for modeling and obtaining working stresses. In the structural analysis, the provisions of NCh 1198 Of. 2006: Wood - Timber Constructions - Calculation (from the Spanish, Madera - Construcciones en madera - Cálculo) (INN, 2006) were taken into account. This was carried out to obtain the admissible stresses in the wood.

\section{Results}

The results of the wood identification study determined that the fifteen samples collected correspond to the species Pseudotsuga menziesii (Oregon Pine). The presence of resin canals (Figure 2A), spiral thickening and uniseriate wood rays (Figure $2 \mathrm{~B}$ ) confirm this fact.

The studies of the basic inspection showed that the main part of the elements that comprise the building are healthy. However, there are some exceptions in the external lower part that show deterioration by the action of insects (Figure $3 \mathrm{~A}$ ) and there is some internal deterioration at the foundations level by rot (Figure 3B). Chemical degradation by defibration was also observed in the external upper levels (Figure 3C).

The instrumental studies related to the verticality of the tower established minimum deviations in the east and west facades. The north and south facades did not exceed two centimeters. Horizontality deviations were not observed.

Figure 2. Optical microscopy from Pseudotsuga menziesii. A. Resin canals - B. Spiral thickenings and uniseriate xylem rays. Source: Self elaboration.
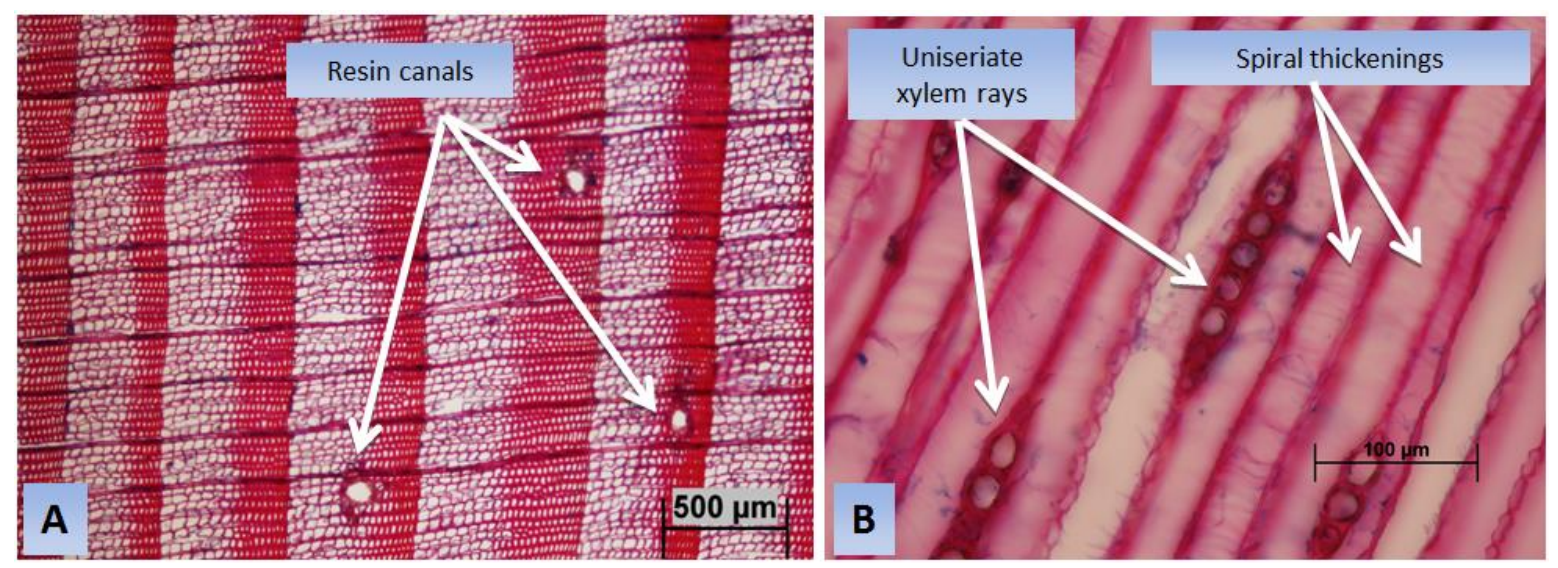

The results of the instrumental inspection through NDT for the five levels of the building, regarding the measurements of moisture content, ultrasonic wave propagation speed, wood density determined through resistography, and temperature and relative humidity are detailed in Table 1 . The determination of the normal density and wood equilibrium moisture content have also been recorded.

Table 2 shows the results of static MOE of foundations, mezzanine level and second level. The determined average value is 4.4 (GPa). The results obtained allow-in accordance with NCh 1198 Of. 2006 -classifying the elements of wood into the structural class F3 (INN, 2006). 
Figure 3. A. External deterioration by the action of social insects - B. Deterioration by rot - existence of fungal mycelium - C. Chemical degradation by superficial defibration - D. Brown rot in the wood of Pseudotsuga menziesii. Source: Self elaboration.
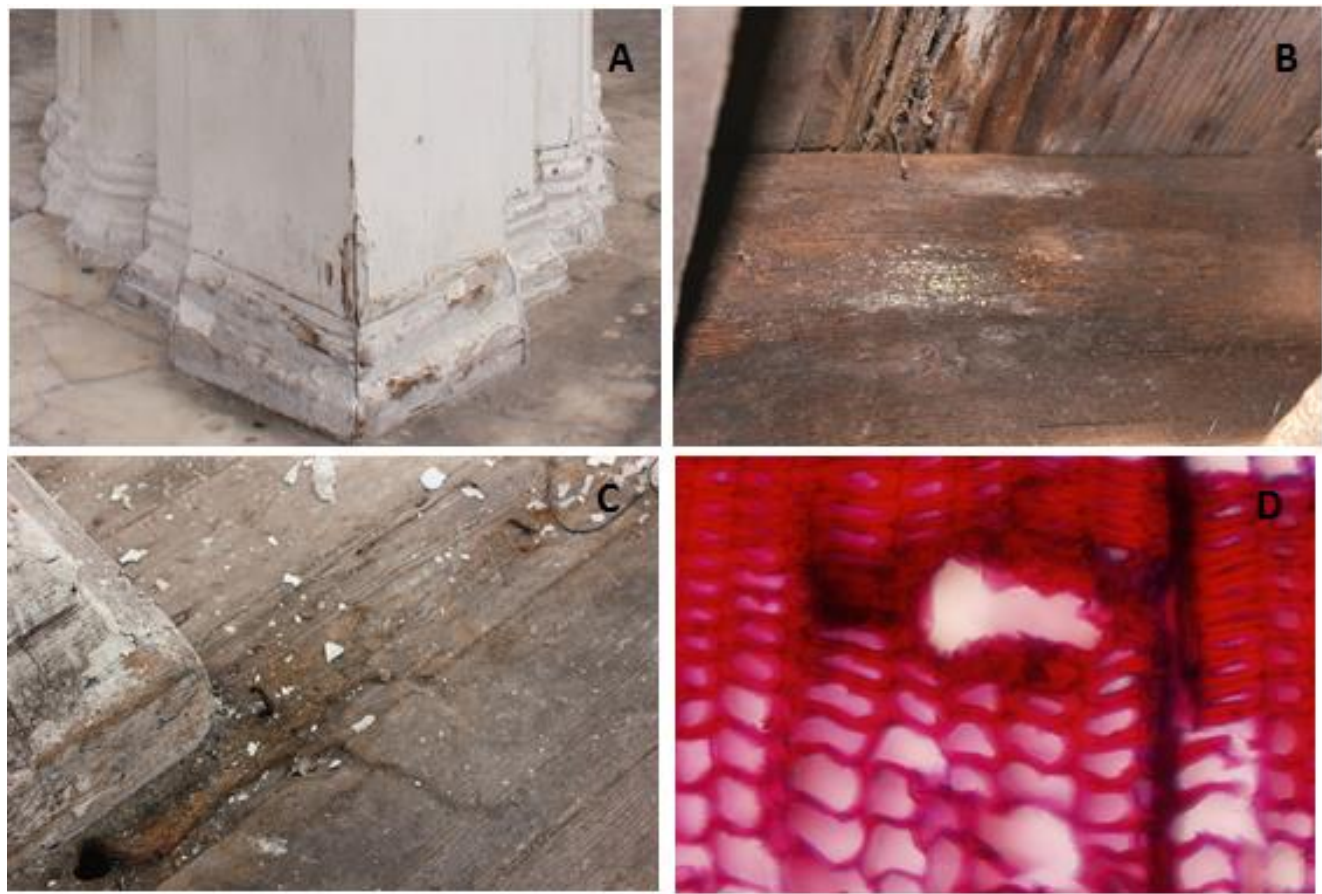

Table 1. Results of the instrumental inspection in the five levels of the tower. Source: Self elaboration.

\begin{tabular}{|c|c|c|c|c|c|c|c|}
\hline Level & $\begin{array}{c}\text { Wood } \\
\text { moisture } \\
\text { content (\%) }\end{array}$ & $\begin{array}{l}\text { Ultrasound } \\
\text { speed }(\mathrm{m} / \mathrm{s})\end{array}$ & $\begin{array}{c}\text { Density } \\
\text { through } \\
\text { resistography } \\
\left(\mathrm{Kg} / \mathrm{m}^{3}\right)\end{array}$ & $\begin{array}{l}\text { Normal } \\
\text { density } \\
\left(\mathrm{Kg} / \mathrm{m}^{3}\right)\end{array}$ & $\begin{array}{c}\text { Average } \\
\text { temperature } \\
\left({ }^{\circ} \mathrm{C}\right)\end{array}$ & $\begin{array}{l}\text { Ambient } \\
\text { relative } \\
\text { humidity } \\
(\%)\end{array}$ & $\begin{array}{l}\text { Wood } \\
\text { equilibrium } \\
\text { moisture } \\
\text { content (\%) }\end{array}$ \\
\hline Foundations & 30 & 3464 & 391 & 345 & 21.3 & 76 & 16 \\
\hline $\begin{array}{l}\text { Mezzanine } \\
\text { level }\end{array}$ & 26 & 4731 & 392 & 366 & 18.5 & 76 & 16 \\
\hline Second level & 25 & 4501 & 435 & 406 & 18.4 & 70 & 14 \\
\hline Third level & 27 & - & 355 & 321 & 17.4 & 75 & 15.5 \\
\hline Fourth level & 22 & - & 373 & 308 & - & - & - \\
\hline Fifth level & 26 & - & 392 & 372 & - & - & - \\
\hline
\end{tabular}

Table 2. Results from the static MOE. Source: Self elaboration.

\begin{tabular}{lc}
\hline Level & Static MOE (GPa) \\
\hline Foundations & 3.5 \\
Mezzanine level & 4.7 \\
Second level & 4.9 \\
\hline
\end{tabular}

Figure 4 shows the structural modeling of the tower. The working stresses obtained through Sap 2000 and the admissible stresses, according to the Chilean regulations, of the most unfavorable elements in flexo-compression and shears are shown in Table 3. The results determined that the working stresses of the building are under the respective admissible stresses. 

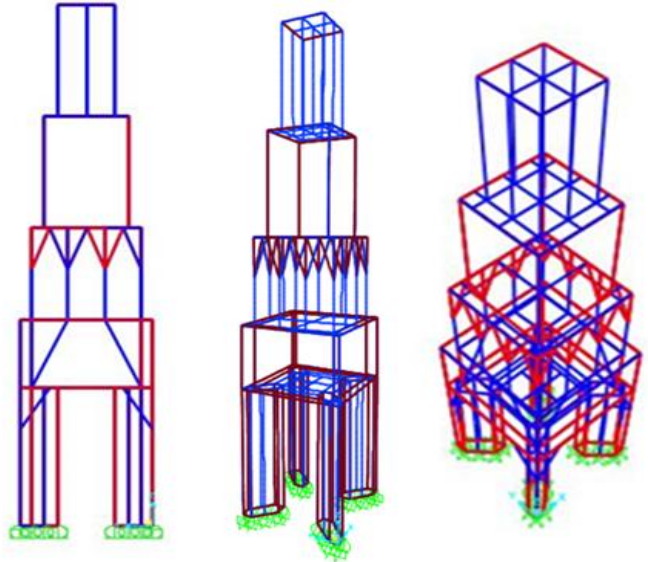

Table 3. Working and admissible stresses. Source: Self elaboration.

\begin{tabular}{cccc}
\hline $\begin{array}{c}\text { Verification in } \\
\text { accordance with NCh } \\
\begin{array}{c}1198 \text { Of. 2006 } \\
\text { (INN, 2006) }\end{array}\end{array}$ & Column 2-4 & Clement & \\
\cline { 2 - 4 } & 0.64 & 0.801 & 0.682 \\
$\begin{array}{c}\text { Flexo-compression } \\
\text { interaction }<1\end{array}$ & 1.9 & 0.7 & 0.7 \\
f wss $\leq \mathrm{F}$ ass & Satisfactory & Satisfactory & Satisfactory \\
\hline
\end{tabular}

$\mathrm{f}$ wss $=$ working shear stress; $\mathrm{F}$ ass $=$ admissible shear stress; $F$ ass $=4.4\left(\mathrm{Kg} / \mathrm{cm}^{2}\right)$

The bibliographic records account that a great part of the Chilean tangible immovable cultural heritage has been built with the wood of the non-native species Pseudotsuga menziesii (Oregon Pine) (Gomez, 2003; García, 2005; Ortiz et al., 2011; Ortiz et al., 2013). The above was possible due to the significant commercial exchange established between Chile and the port of California, United States, at the flourishing period of the saltpeter industry (Advis, 2009). The material was transported as ship ballast (Hermosilla et al., 2000).

The results of the basic inspection do not show signs of deep damage. Deterioration by the action of larval cycle insects and social insects are evident and are apparently inactive. The deterioration by brown rot is consistent with the corresponding wood substrate of a conifer species (Schmidt, 2006), which is shown through the loss of the original shape of the cells due to the depolymerization of cellulose (Figure 3D). Regarding the degradation by defibration caused by the existence of salt in the environment, this is related to the proximity of the building to the coast of Iquique. This can be explained by the influence of the marine mass and the Humboldt current on the coastal desert climate of the city, which is presented with high humidity and low probability of rainfall. The defibration, as described in the literature, only causes a superficial degradation (Kučerová et al., 2008). Therefore, it does not present any risk for the integrity of the tower due to its shallow depth. The analysis of the results of the geometrical evaluation of the four facades determines that the deviations are minimum and negligible. The observed deviations are attributable to the construction process and it is ruled out that these are caused by external forces or by a resistant behavior.

The values of moisture content of wood, with the exception of the fourth level (22\%), are close to the Fibre Saturation Point (FSP) so there is a high probability that the material can reach the condition of liquid water inside the cell cavity. According to the recorded values of temperature and relative humidity, the equilibrium moisture content of wood should be around 15\% (Table 1) (Kollman, 1959). The results show a significant difference between the wood moisture contents and the values of equilibrium moisture content, according to the estimates performed based on the prevailing environmental conditions on each of the building levels. This difference can be explained due to the existence of moisture sources, other than the environment, related to constructions adjacent to the tower and that are not properly waterproofed, thus allowing the entry of water at the foundations level. This favors the biodeterioration conditions. 
The value of ultrasonic wave propagation speed, at a longitudinal direction, and at $13.6 \%$ of moisture content for the wood of Pseudotsuga menziesii corresponds to $4706 \mathrm{~m} / \mathrm{s}$ (Niemz et al. 1994). The results obtained in the evaluation, for the mezzanine and second level, determined slightly higher and slightly lower longitudinal speed values in relation to what was reported by Niemz et al (1994). This establishes that, for the mezzanine and second level, the wood is healthy. However, the speed measured at the foundation level indicates that the wood has lost at least $50 \%$ of its mechanical strength (Ross \& Hunt, 2000).

The resistographic measurements reflect the global state of the evaluated element. In addition, it is possible to estimate the wood density in accordance with different correlations reported in the literature (Acuña et al., 2011; Mantilla \& Santos, 2013). The densities recorded through resistography and subsequently corrected, per moisture, to normal density values (Table 1), which considers a $12 \%$ of moisture content (Corma, 2003), determined a significant decrease in relation to the normal density of $446\left(\mathrm{~kg} / \mathrm{m}^{3}\right)$-according to INN (1986)-established for healthy wood of Pseudotsuga menziesii. The performed evaluation determined that the evaluated wood elements are affected by biodeterioration agents and their damage is not visually evident in a complete way. The current state of wood reflects that it is under the recommendations of Chilean regulations. The above has an impact on its mechanical properties.

NDT integration with respect to moisture content values (Figure 5A, 5C), ultrasound speed (5B) and normal density obtained through resistography (5D) allow estimating the static MOE in bending. The evident decrease in wood density is reflected in a low MOE value. The aforementioned considerations are the basis for structural classification, being F3 the lowest category in the Chilean regulation. Notwithstanding the above, the structural formation and the low weight of the tower have contributed to a proper behavior to seismic requirements to which the building has been subject. Although the working stresses do not exceed the admissible stresses, it is important to mention that some elements at the foundations level are severely affected by biodeterioration agents. The evident decrease in the mechanical properties of these elements is worrisome. Therefore, performing intervention actions immediately in order not to jeopardize its stability is required.

Figure 5. NDT integration in the clock tower: A. Wood hygrometry - B. Ultrasonic wave propagation speed - C. Sensors of temperature and relative humidity - D.
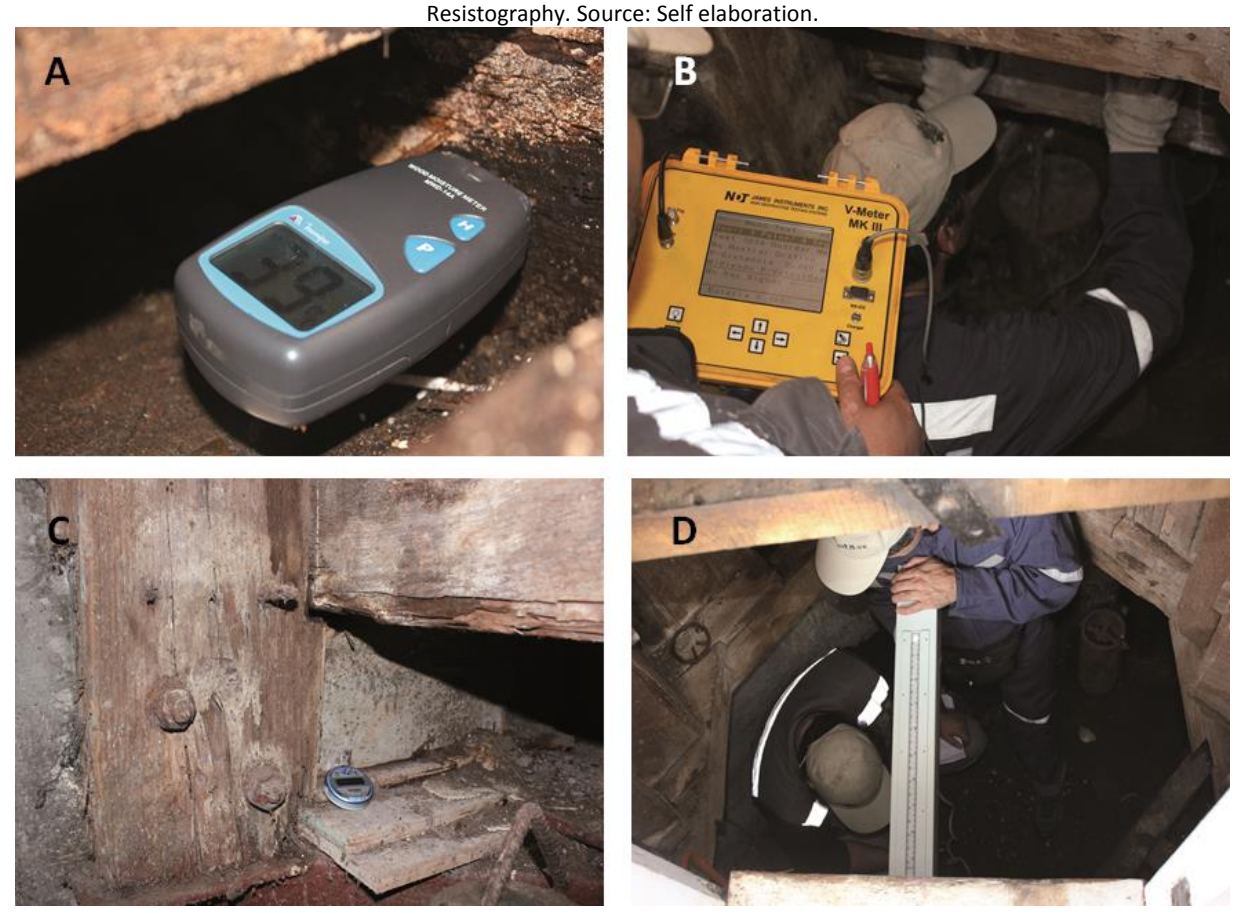

The results of visual inspections partially reflect the real condition of a building under evaluation. However, through the NDT integration, it is possible to obtain more accurate and objective information that contributes to a reliable development of the modeling and analysis of this structure. The above is comprised of judgment elements for decision making in the development of intervention projects. 
The study carried out through NDT evaluated the preservation status of lquique clock tower and its results indicate that the elements that comprise this structure are affected by biodeterioration agents.

The structural analysis determined that the working stresses do not exceed the admissible stresses. However, and facing the evident deterioration of the wood at the foundations level, it is necessary to perform intervention actions in the building.

The use of NDT allows providing accuracy in the evaluation process.

Acknowledgments

This article is dedicated to the professor of the School of Civil Construction of Universidad de Valparaiso and author of this publication, Mr. Alberto Moya Arredondo. Countless generations of Civil Engineers and Construction Engineers attest to his professional, academic and human quality.

This work was supported by Fondo Nacional de las Artes FONDART in the 2015 call.

Acuña, L., Basterra, A., Casado, M., López, G., Ramón-Cueto, G., Relea, E., Martínez, C., \& González, A. (2011). Aplicación del resistógrafo a la obtención de la densidad y a la diferenciación de especies de madera. Materiales de Construcción, 61(303), 451-464.

Advis, P. (2009). Creación del teatro municipal de Iquique y su contexto histórico urbano. Revista Ciencias Sociales, (22), 23-55.

Basterra, A., López, G., Ramón-Cueto, G., Acuña, L., \& Casado, M. (2008) On site diagnosis and assessment of the nave timber structure of Segovia cathedral (Spain) using non destructive techniques. In: On Site Assessment of Concrete, Masonry and Timber Structures: 1-2 September 2009. Como Lake, Italia.

Basterra, A., Acuña, L., Casado, M., Ramón-Cueto, G., \& López, G. (2009). Diagnóstico y análisis de estructuras de madera mediante técnicas no destructivas: aplicación a la Plaza Mayor de Chichón (Madrid). Informes de la Construcción, 61(516), 21-36. DOI https://doi.org/10.3989/ic.09.016.

Basterra, A., Balmori, J., \& Casado, M. (2017). La armadura de cubierta de la nave central de la Iglesia del Convento de San Francisco en Medina de Rioseco (Valladolid). In: II Congreso hispanoamericano, X Congreso Nacional de Historia de la Construcción: 3-7 octubre 2017. Donostia-San Sebastián, España.

Blanchette, R.A., \& Simpson, E. (1992). Soft rot decay and wood pseudomorphs in an ancient coffin (700 BC) from tumulus MM at Gordion, Turkey. International Association of Wood Anatomists Bulletin, 13, 201-213.

Chauhan, S., \& Sethy, A. (2016). Differences in dynamic modulus of elasticity determined by three vibration methods and their relationship with static modulus of elasticity. Maderas Ciencia y Tecnología, 18(2),373-382. DOI: http://dx.doi.org/10.4067/S0718- 221X2016005000034.

Corma. (2003). Compendio de directrices para enseñanza en ingeniería. Retrieved from https://www.madera21.cl/project-view/compendio-de directrices-para-ensenanza-en-ingenieria

Coscollano, J. 2003. Restauración y Rehabilitación de Edificios de Madera. Editorial Paraninfo, Madrid, España.

Díaz-Vaz, J. (1979). Claves para la identificación de maderas de árboles nativos y cultivados en Chile. Bosque, 3(1),15-25.

Donoso, C. (2003). El puerto de Iquique en tiempos de administración peruana. Historia, 36, 123-158.

Emerson, R., Pollock, D., Kainz J., Fridley K., Mclean, D., \& Ross, R. (1988). Nondestructive evaluation techniques for timber bridges. In: $V$ World Conference on Timber Engineering. 17-20 August 1988. Montreux, Switzerland.

Fox, H. (2012). Memorias urbanas, cotidianeidad, identidad y trascendencia de la ciudad. Urbano, (25), 8-16.

García, M. (2005). Sewell. Patrimonio de la minería chilena. (Bachelor of Arts Thesis, The University of Chile, Santiago, Chile). Retrieved from http://www.tesis.uchile.cl/tesis/uchile/2005/garcia_m2/sources/garcia_m2.pdf

Gómez, L. (2003). En torno a la singularidad de Sewell. Revista de Urbanismo, (8),22-42.

Hermosilla, P., Ortega, O., \& Pávez, I. (2000). Antologia. Revista de Arquitectura, 10(11),49-55.

Kollman, F (1959). Tecnología de la madera y sus aplicaciones. Vol I. Instituto forestal de investigaciones y experiencias, Madrid, España. 675p.

Kučerová, I., Ohlídalová, M., Frankl J., Kloiber, M., \& Michalcova, A. (2008) Defibring of historical roof beam caused by ammonium sulphate and ammonium phosphates based fire retardants. In: International Conference on wood science for preservation of cultural heritage: Mechanical and biological factors: 5-7 November 2008. Braga, Portugal. 
Mantilla E., \& Santos, N. (2013). Estimativa da densidade aparente, resistência à compressão e módulo de elasticidade da madeira por meio do resistógrafo. Construindo, 5(1), 45-51.

Mineduc. (1987). Declaración Monumento histórico torre del reloj plaza Prat, de lquique, I región de Tarapacá. Retrieved from https://www.monumentos.gob.cl/servicios/decretos/433_1987

Instituto Nacional de Normalización (INN). (1986). Madera-Parte 2: Determinación de la densidad. (NCh176/2.Of86). Santiago, Chile: Autor.

Instituto Nacional de Normalización - (INN). (1996). Diseño sísmico de edificios. (NCh433.Of96). Santiago, Chile: Autor.

Instituto Nacional de Normalización (INN). (2006). Madera-Construcciones en madera-Cálculo. (NCh1198.0f2006). Santiago, Chile: Autor.

Instituto Nacional de Normalización (INN). (2010). Diseño estructural-Disposiciones generales y combinaciones de carga. (NCh3171.Of2010). Santiago, Chile: Autor.

Niemz, P., Aguilera, A., \& Rolleri, A. (1994). Velocidad de propagación del sonido en algunas especies creciendo en Chile y su relación con propiedades físicas. Bosque, 15(2), 49-54.

Ortiz, R., Moreno, L., Ramirez, R., \& Olivero, P. (2011). Determinación de los modelos de biodeterioro en elementos de madera producidos por hongos de pudrición en edificaciones de la zona de conservación histórica de Valparaíso, Chile. Revista de la Construcción, 10(2),82-89. DOI http://dx.doi.org/10.4067/S0718-915X2011000200008.

Ortiz, R., Navarrete J., Párraga M., Carrasco I., De la Vega, E., Ortiz, M., \& Blanchette, R. (2013). Deterioration, decay and identification of fungi isolated from wooden structures at the Humberstone and Santa Laura Saltpeter Works: A World Heritage Site in Chile. International Biodeterioration and Biodegradation, 86,309-316. DOI http://dx.doi.org/10.1016/j.ibiod.2013.10.002.

Ortiz, R., Jamet, A., Moya, A., González, M., Varela, MP., Hernández, M., Fuentes, R., Díaz, P., \&Navarrete, J. (2015). Diagnóstico de la Planta de Lixiviación de la oficina Salitrera Santa Laura en Chile. Patrimonio de la Humanidad. Informes de la Construcción, 67(540), e115. DOI http://dx.doi.org/10.3989/ic.14.101.

Ortiz, R., Fuentes, N., Jamet, A., Moya, A., González, M., Varela, M. Paz, Ramírez, A., Adofacci, G., \& Martínez, P. (2017). Evaluación resistográfica en elementos de maderas desfibradas de la torre de lixiviación de la oficina salitrera Santa Laura en Chile. Patrimonio de la Humanidad. Informes de la Construcción, 69(547): e209. DOI http://dx.doi.org/10.3989/id54678.

Rodríguez, J. (1998). Patología de la Madera. Fundación del Valle de Salasar. Editorial Mundi - Prensa. España.

Ross, R., \& Pellerin, R. (1994). Nondestructive testing for assessing wood members in structures. A review. Forest Products Laboratory. Retrieved from https://www.fpl.fs.fed.us/documnts/fplgtr/fplgtr70.pdf

Ross, R., \& Hunt, M. 2000. Stress wave timing nondestructive evaluation tools for inspecting historic structures. A guide for use and interpretation. Retrieved from https://www.fpl.fs.fed.us/documnts/fplgtr/fplgtr119.pdf

SAP2000 v20. Integrated Software for Structural Analysis and Design. Computers and Structures Inc., Berkeley, California.

Schmidt, O., (2006). Wood and tree fungi: Biology, Damage, Protection, and use. Berlin, Heidelberg: Springer-Verlag: Berlin Heidelberg.

Tanasoiu, V., Miclea, C., \& Tanasoiu, C. (2002). Nondestructive testing techniques and piezoelectric ultrasonics transducers for wood and built in wooden structures. Journal of Optoelectronics and Advanced Materials, 4 (4), 949 - 957. 